\title{
Factors associated with weight for height and skinfold thickness in British children
}

\author{
Enric Duran-Tauleria, Roberto J Rona, Susan Chinn
}

\begin{abstract}
Study objective - To examine the associations of social and biological factors with measures of obesity in children.

Design - The study had a cross sectional design.

Setting - The analyses were based on data from two national study of health and growth cross sectional surveys. The "representative sample" comprised 1990 data from 22 English areas and 1990-91 data from 14 Scottish areas; the "inner city sample" comprised 1991 data from 20 English areas.

Participants - The subjects were primary school children aged mainly 5-11 years living in England and Scotland. The "representative" sample included 10628 children - 6463 living in England and 4165 living in Scotland. The "inner city" sample included 7049 children - 2183 white, 1124 Afro-Caribbean, 2696 Indian subcontinent, and 1046 from other groups. Due to missing values on continuous variables, 8374 children were included in the analyses.
\end{abstract}

Measurements and main results - The relation between social environment and childhood overweight was studied using several indicators of obesity. Triceps, subscapular, the sum of triceps and subscapular skinfolds, and weight for height were used as dependent variables. The analyses were carried out in two stages. Firstly, multiple linear regression analyses were used to assess the factors associated with dependent variables treated as continuous. Secondly, multiple linear logistic regression analyses were used to examine the association between independent factors and overweight and fatness defined as binary variables. Birth weight, mother's body mass index (BMI), and father's BMI were consistently associated $(p<0 \cdot 001)$ in all models and were the variables that contributed most to the explained variation in the dependent variables. In the multiple regression analyses there was a consistent interaction between the effects of ethnic origin and family size on each outcome variable. In the logistic regression analyses the interaction was not significant, and highly significant associations between both overweight and fatness with the number of children were shown. Ethnic group was not significantly associated with overweight but it was with fatness. The strengths of the remaining significant associations were slight and inconsistent in relation to the dependent variables or the type of analysis.

Conclusion - Very few variables were associated with measures of overweight and fatness. The only useful factor that was highly associated with all measures of fatness was the parents' BMI. Strategies to prevent childhood obesity should be aimed at the total population and special emphasis should be placed on families in which one or both parents are overweight.

( $(\mathcal{E}$ Epidemiol Community Health 1995;49:466-473)

Obesity is one of the most important public health problems of our time. ${ }^{1}$ In adults, it increases the risk of coronary heart disease, type II diabetes, gall bladder disease, and some forms of cancer. ${ }^{1-9}$ Although the effects of childhood obesity have been studied less, clinically obese children have also been shown to have an increased risk of long term morbidity and mortality. ${ }^{10-12}$ Gortmaker et al ${ }^{13}$ have shown that being overweight during adolescence has important social and economic consequences, which could be greater than those of many other chronic physical conditions.

Increases in the body mass index (BMI) have been reported in Britain for young adult women $^{1415}$ and in Sweden for men during the 1980 s. $^{16}$ The prevalence of obesity has also increased for children ${ }^{17}$ and for adults ${ }^{18}$ in the United States. Recently, increasing trends in weight for height and triceps skinfold have been reported for English girls and Scottish children. ${ }^{19}$

The risk of overweight children becoming obese in adulthood is not well known. A study reported that only $21 \%$ of obese 36 year olds had been obese at 11 years of age, and when social factors were taken into account the predicted percentage was much lower. ${ }^{20}$ Other studies have reported that between $40 \%{ }^{21}$ and $85 \%^{22-24}$ of overweight children will become obese adults.

Rolland-Cachera et $a l^{25}$ have suggested that age at rebound, which is the onset of the second period of rapid growth in body fat, is the best predictor of the subsequent development of fatness but the reasons for the rebound have not been established. Interventions to prevent childhood obesity could prevent adult obesity as well as reduce the risk of morbidity and mortality in adult life. However, to implement effective interventions the knowledge of the risk factors associated with childhood obesity ${ }^{26}$ is required and these remain controversial and poorly understood..$^{27}$ 
During past decades, several studies have investigated the association between social, biological, and environmental factors and childhood obesity. The season of measurement, ${ }^{26}$ ethnic group, ${ }^{2829}$ parents' weight and height, ${ }^{30-33}$ family size, ${ }^{32}$ birth weight, ${ }^{33}$ excessive television viewing, and short sleep $^{28}$ were all variables found associated with proxy measures of obesity. Social class is perhaps the variable studied most. Some studies reported strong associations, ${ }^{34}$ but others have shown that after adjustment for other confounding factors, social class explains only a small percentage of variation in weight for height. ${ }^{33}$ These studies included in the analysis only a few factors previously associated with overweight. Differences in the way that potential confounders were included in the analysis could have led to the different results.

Limited understanding of the associations between social factors and overweight has led to the proposal of different prevention strategies. Some investigators have suggested strategies focused on high risk groups ${ }^{2834}$ while others have indicated population based strategies. ${ }^{29} 32$

In the national study of health and growth (NSHG), a monitoring system to assess nutritional status in primary school children, analyses have been carried out to assess the factors that influence weight for height and triceps skinfold in British children ${ }^{33}$ and to estimate the change in these anthropometric measurements over time. ${ }^{1935}$ In the previous analyses we used a limited number of variables to characterise the biological background and the social environment.

In the analysis undertaken, we included new variables reflecting other aspects of the child's environment collected in the NSHG 1990 and 1991 surveys in order to re-examine the associations between social and biological factors and obesity. The implications of the findings for primary prevention are discussed.

\section{Methods \\ SUBJECTS}

Data were taken from the NSHG, which was set up in 1972 to monitor growth of primary school children aged 5-11 years living in England and Scotland. Two samples were recruited into NSHG. The initial sample included children from schools in 22 employment exchange areas in England and six in Scotland, which were selected by stratified random sampling. ${ }^{36}$ Children were eligible to take part while attending schools selected for the study. This sample was surveyed annually from 1972 to 1982 and in even years thereafter for England. The Scottish sample was enhanced by a further eight areas in 1983, and data were collected over a two year period. The characteristics of children from this sample are similar to those of the general population ${ }^{29}{ }^{37}$ and the sample will be referred to as "representative" in this paper.

In 1983, a second sample was recruited by identifying 10 electoral wards in England with a high prevalence of overcrowding, male unemployment, or shared household amenities.
In addition five wards were selected which had a high proportion of families from Indian subcontinent backgrounds, and five which had a high proportion of families from Afro-Caribbean backgrounds. The wards selected because of their ethnic composition also had characteristics of deprivation. ${ }^{29}$ This sample will be referred to as "inner city". For the present analysis, data were analysed together for the 1990 English, the 1990-1991 Scottish representative sample, and the 1991 English inner city sample.

\section{MEASUREMENTS}

Children were measured at school by school nurses and $10 \%$ of the measurements were checked by a full time fieldworker from the study team. Height was measured on a specially designed stadiometer (Holtain) using the method described by Tanner, Whitehouse, and Takaishi. ${ }^{38}$ Height was recorded to the last $0.1 \mathrm{~cm}$. Weight was recorded to the last $100 \mathrm{~g}$ : children were wearing underclothes, normally pants only. Triceps and subscapular skinfold thickness were measured as described by Tanner and Whitehouse, ${ }^{39}$ except that for the triceps skinfold the midpoint between the top of the acromion and olecranon was marked with the arm hanging straight rather than bent. Harpenden skinfold callipers were used for the measurements. Readings were recorded to the last $0.2 \mathrm{~mm}$ on the calliper scale.

\section{OUTCOME VARIABLES}

The weight for height index ((weight-9)/ height $\mathrm{t}^{3 \cdot 7}$, where height is in $\mathrm{m}$ and weight in $\mathrm{kg}$ ) and triceps, subscapular, and triceps plus subscapular skinfold thickness standard deviation scores (SDS) were used as outcome variables. The weight for height index is a measure of overweight that includes an assessment of many tissues besides fat, and triceps and subscapular skinfolds are direct measures of fatness. We used four outcome variables in the analysis in order to check if there was a different pattern of association depending on the outcome measure used.

As height ${ }^{40}$ and weight ${ }^{41}$ each show increasing variation with age in children, it is necessary to transform data by including several age groups before the analysis. SDS expresses a measurement for a child, transformed as necessary to a normal distribution, as the difference from the reference group mean for that child's age and sex, divided by the SD for the age and sex, so that for the reference group mean SDS is zero and the SD is one.

Chinn et $a l^{41}$ showed that log ((weight-9)/ height $\left.{ }^{3.7}\right)$ has constant variance, and is approximately normally distributed, so SDSs were calculated from its distribution. SDSs for triceps skinfold thickness were calculated as described by Cole. ${ }^{42}$ This required smoothing the mean, the coefficient of variation and a third parameter accounting for skewness over age. All SDSs were calculated using the English 1990 data as standard. 
EXPLANATORY VARIABLES

In addition to the children's measurements, the child's parent or guardian was asked to complete a self administered questionnaire containing questions relating the child's health and the social background of the family. The questionnaire also requested information concerning the parents' height and weight and the child's birth weight.

\section{Explanatory continuous variables}

The explanatory factors which were used in this study as continuous variables were the maternal and paternal BMI, the mother's age at child's birth, and the child's birth weight.

\section{Categorical variables}

Categorical variables were classified as follows:

- Twin or triplet (classified as yes, no, and unknown);

- Family size (specifying the number of children in the family and classified as: up to eight or more and unknown);

- Type of lunch at school (classified as school meal, home meal, packed lunch, buy lunch outside school, any combination including school and unknown);

- Free school meals (classified as received, not received, not applicable, and unknown);

- Vegetarian (classified as yes, no, unknown);

- Child drinking milk at school (classified as yes, no, and unknown);

- Hours worked by the mother outside the home (classified as fewer than 15/week, 15-25, more than 25, no outside work, and unknown); - Mother's and father's highest education (classified as primary, secondary, commercial or technical, university, no school education, and unknown);

- One parent family (classified as both parents living at home, only child's mother living at home, only child's father living at home, neither child's father and mother living at home (child guardian) and unknown);

- Paternal social class (classified as I, II, IIIN, IIIM, IV, V, and unknown);

- The receipt of benefits - unemployment benefit, income support, and family credit (classified as yes, no, and unknown);

- Ethnic group of the child - classified according to the language spoken at home and by the fieldworker's subjective assessment of the child's ethnic group. The categories used in this analysis of ethnic group were as follows: white living in England (1990 representative sample), white living in Scotland (1990/1991 representative sample), white living in a inner city area (1991 inner city sample), Afro-Caribbean, children speaking Punjabi, Gujarati, Urdu, others from Indian subcontinent and other Asian or Mediterranean;

- A variable which defined the relationship between the father's and mother's overweight was created as follows. Firstly, the mother's and father's BMIs were divided into quartiles. Mother's BMI in the top quarter which had a value equal to or higher than 25.38 and father's $\mathrm{BMI}$ in the top quarter with a value equal to or higher than $26 \cdot 23$ were considered overweight. Secondly, a variable was defined with four categories as follows: neither mother nor father overweight, only the father overweight, only the mother overweight, and both the mother and father overweight.

- To investigate a possible interaction between birth weight and age, age was categorised in four groups: children $<7$ years old, from 7 to 8 , from 9 to 10 , and $>10$.

Cases containing values in the outcome variables outside the range -4.5 to +4.5 SDs and those with missing values on the continuous variables were excluded from the analysis. For categorical variables containing missing values an "unknown" category was defined for each variable.

\section{STATISTICAL ANALYSIS}

Two main analyses were carried out in this study. Firstly, a multiple linear regression analysis was used to explore independent associations between explanatory variables and any of the outcome variables (treated as continuous). Four models were fitted, one for each dependent variable (outcome) with explanatory variables described above. Backward elimination of variables was carried out and the final model included only variables significant at the $5 \%$ level. Independent variables were entered as continuous or categorical according as previously indicated. Secondly, a logistic regression analysis was performed to assess the relationship between child's overweight (treated as a binary variable) and the independent factors.

Although there is not a clear criterion for the cut off point to define overweight in children as there is in adults, several studies ${ }^{202728}$ have carried out analysis using weight for height, classified as a binary variable (normal weight/ overweight), obtaining different patterns of association. In order to determine whether there is a different pattern of association when dependent variables are used as a continuous or binary variable, multiple linear logistic regression analyses were used with the outcome variables treated as binary variables. Those in the first, second, and third quarter were classified as not overweight and those in the top quarter were considered overweight. In order to see differences in the odds ratios (ORs) at different levels, we introduced birth weight categorised in quartiles in this analysis. Backward elimination was carried out until the $p$ values of all the remaining independent variables were less than 0.05 .

\section{Results}

Data for the 10628 children of the representative sample (6463 living in England, 4165 living in Scotland) and for the 7049 of the inner city sample (2183 white children, 1124 Afro-Caribbean, 2696 Indian subcontinent, and 1046 from other groups) were available for the analysis.

Information on continuous and categorical explanatory variables was collected from the 
Table 1 Percentage of unknown values for outcome and explanatory variables by sample

\begin{tabular}{llll}
\hline & $\begin{array}{l}\text { England 1990 } \\
(n=6463) \\
(\%)\end{array}$ & $\begin{array}{l}\text { Scotland 1990-1991 } \\
(n=4165) \\
(\%)\end{array}$ & $\begin{array}{l}\text { Inner city 1991 } \\
(n=7049) \\
(\%)\end{array}$ \\
Variables & & & \\
\hline Outcome: & $0 \cdot 7$ & $0 \cdot 3$ & $5 \cdot 7$ \\
Weight for height (SDS) & $0 \cdot 4$ & $0 \cdot 2$ & $5 \cdot 3$ \\
Triceps skinfold (SDS) & $0 \cdot 3$ & $0 \cdot 3$ & $5 \cdot 3$ \\
Subscapular skinfold (SDS) & $0 \cdot 5$ & $0 \cdot 3$ & $5 \cdot 3$ \\
Triceps + subscapular skinfold (SDS) & $0 \cdot 5$ & & \\
Explanatory (categorical): & & & $25 \cdot 3$ \\
Family size & $11 \cdot 4$ & $5 \cdot 4$ & $27 \cdot 8$ \\
Twin or triplet & $10 \cdot 0$ & $7 \cdot 0$ & $19 \cdot 7$ \\
School lunch & $7 \cdot 4$ & $3 \cdot 4$ & $28 \cdot 4$ \\
Lunch free & $14 \cdot 7$ & $8 \cdot 9$ & $22 \cdot 8$ \\
Vegetarian & $8 \cdot 7$ & $4 \cdot 2$ & $21 \cdot 7$ \\
Milk at school & $10 \cdot 0$ & $4 \cdot 5$ & $21 \cdot 7$ \\
Mother at work & $6 \cdot 8$ & $4 \cdot 8$ & $24 \cdot 8$ \\
Mother's education & $8 \cdot 9$ & $4 \cdot 3$ & $31 \cdot 7$ \\
One parent family & $8 \cdot 0$ & $3 \cdot 7$ & $55 \cdot 7$ \\
Father's education & $11 \cdot 5$ & $7 \cdot 0$ & $49 \cdot 9$ \\
Father's social class & $26 \cdot 4$ & $24 \cdot 8$ & $29 \cdot 6$ \\
Unemployment benefit & $18 \cdot 2$ & $17 \cdot 4$ & $48 \cdot 3$ \\
Income support & $12 \cdot 3$ & $8 \cdot 8$ & \\
Family credit & $17 \cdot 1$ & $15 \cdot 8$ & $58 \cdot 7$ \\
Explanatory (continous): & & & $52 \cdot 7$ \\
Father's body mass index & $30 \cdot 1$ & $39 \cdot 7$ \\
Mother's body mass index & $20 \cdot 5$ & $25 \cdot 4$ \\
Birth weight & $11 \cdot 7$ & $8 \cdot 5$ & $2 \cdot 5$ \\
Mother's age at child's birth & $8 \cdot 6$ & $4 \cdot 4$ & \\
\hline
\end{tabular}

SDS $=$ standard deviation score.

Table 2 Mean (SEM) of outcome variables included and excluded by sample

\begin{tabular}{|c|c|c|c|c|c|}
\hline \multirow[b]{2}{*}{ Sample } & \multirow[b]{2}{*}{ No } & \multirow[b]{2}{*}{$(\%)$} & \multicolumn{3}{|l|}{$S D S$} \\
\hline & & & $\begin{array}{l}\text { Weight for height } \\
\text { Mean (SEM) }\end{array}$ & $\begin{array}{l}\text { Triceps } \\
\text { Mean (SEM) }\end{array}$ & $\begin{array}{l}\text { Subscapular } \\
\text { Mean (SEM) }\end{array}$ \\
\hline \multicolumn{6}{|l|}{ England: } \\
\hline Included & 4062 & $(62 \cdot 8)$ & $0.004(0.01)$ & $-0.009(0.01)$ & $-0.013(0.01)$ \\
\hline Excluded & 2401 & $(37 \cdot 1)$ & $0.004(0.06)$ & $0.002(0.06)$ & $0.010(0.06)$ \\
\hline \multicolumn{6}{|l|}{ Scotland: } \\
\hline Included & 2450 & $(58 \cdot 8)$ & $0.055(0.02)$ & $-0.009(0.02)$ & $0.130(0.01)$ \\
\hline Excluded & 1715 & $(41 \cdot 1)$ & $0.080(0.02)$ & $-0.010(0.02)$ & $0.160(0.02)$ \\
\hline \multicolumn{6}{|l|}{ Inner city: } \\
\hline Included & 1862 & $(26 \cdot 4)$ & $-0.140(0.02)$ & $-0.160(0.02)$ & $0.140(0.02)$ \\
\hline Excluded & 5187 & $(73.5)$ & $-0.170(0.01)$ & $-0.220(0.01)$ & $0.160(0.01)$ \\
\hline
\end{tabular}

SDS $=$ standard deviation score.

Table 3 Associations between weight for height and biological and social environment factors. Models defined using multiple regression analysis

\begin{tabular}{|c|c|c|}
\hline & \multicolumn{2}{|c|}{ Weight for height (SDS) } \\
\hline & Coefficient (SEM) & $p$ value \\
\hline $\begin{array}{l}\text { Intercept } \\
\text { Mother's education: } \\
\text { Primary school } \\
\text { Secondary education } \\
\text { Further education } \\
\text { University/Polyt. } \\
\text { No school education } \\
\text { Unknown }\end{array}$ & $\begin{array}{l}-3.469(0.094) \\
0 \\
0.076(0.068) \\
0.108(0.071) \\
0.099(0.074) \\
-0.147(0.111) \\
0.378(0.129)\end{array}$ & 0.0125 \\
\hline $\begin{array}{l}\text { One parent family: } \\
\text { Both parents at home } \\
\text { Only mother at home } \\
\text { Only father at home } \\
\text { Neither at home }\end{array}$ & $\begin{array}{l}0 \\
0 \cdot 102(0 \cdot 033) \\
0 \cdot 337(0 \cdot 137) \\
0 \cdot 057(0 \cdot 100)\end{array}$ & 0.0022 \\
\hline $\begin{array}{l}\text { Mother's BMI } \\
\text { Father's BMI }\end{array}$ & $\begin{array}{l}0.049(0.002) \\
0.068(0.003)\end{array}$ & $\begin{array}{l}0.0001 \\
0.0001\end{array}$ \\
\hline $\begin{array}{l}\text { Mother's hours of work: } \\
\text { More than } 25 \mathrm{~h} / \mathrm{wk} \\
\text { Between } 15-25 \mathrm{~h} / \mathrm{wk} \\
\text { Less than } 15 \mathrm{~h} / \mathrm{wk} \\
\text { No work outside home } \\
\text { Unknown }\end{array}$ & $\begin{array}{l}0 \\
-0.050(0.034) \\
-0.085(0.038) \\
-0.104(0.031) \\
-0.052(0.094)\end{array}$ & 0.0175 \\
\hline Ethnic origin and family size interaction: & * & 0.0190 \\
\hline Birth weight $(<7 \mathrm{y})$ & $0.309(0.048)$ & \\
\hline $\begin{array}{l}\text { Birth weight and age interaction: } \\
\text { Difference in slope from }<7 \mathrm{y} \text { age group } \\
7-8 \mathrm{y} \\
9-10 \mathrm{y} \\
>10 \mathrm{y}\end{array}$ & $\begin{array}{r}0.004(0.061) \\
-0.135(0.060) \\
-0.153(0.063)\end{array}$ & $0 \cdot 004$ \\
\hline $\mathbf{R}^{2}$ & $0 \cdot 13$ & \\
\hline
\end{tabular}

* 80 levels not shown, but explained in the text. SDS = standard deviation score; $\mathrm{BMI}=$ body mass index. self administered questionnaire which parents or guardians completed. The response rate was $92 \cdot 3 \%$ for the representative sample and $85.3 \%$ for the inner city sample, but there was variation in the degree of completeness according to the type of variable and sample.

Table 1 shows the number and percentage of unknown values for the dependent and independent categorical and continuous variables. A very small number of children had missing values for dependent variables. Missing values were higher in the inner city sample and they were mainly due to refusal to measurement or not being at school on the survey day.

Explanatory continuous variables had a higher proportion of missing values, especially for mother's and father's BMI. The highest missing values were for the father's BMI, mainly because of missing weight. In the inner city sample, $57 \%$ of values for weight were missing in contrast to $29.4 \%$ in the Scottish sample and $28.8 \%$ in the English sample. Missing values for father's height were $35.0 \%$ for the inner city sample, in contrast with $11.6 \%$ in the Scottish sample and $15.6 \%$ in England. Similar proportions of missing values were observed for mother's weight and height, but these were slightly lower. In the inner city sample the father's BMI had the highest percentage of missing values $(58 \cdot 7 \%)$. Birth weight and mother's age at the child's birth had a lower number of missing values, but proportions were also higher in the inner city sample $-39 \cdot 7 \%$ and $25 \cdot 2 \%$ respectively. The same pattern was shown for categorical variables in general, with a lower percentage of missing values, except for social class, and the highest percentage missing for the inner city sample.

Those children with missing values for continuous variables were excluded from the analysis. After all exclusions, data from 8374 $(47 \cdot 3 \%)$ children were available for analysis. Table 2 shows the number and percentage of inclusions and exclusions by sample. The highest number of exclusions was from the inner city sample $-5187,73 \cdot 5 \%$, compared to $41 \cdot 1 \%$ for the Scottish sample and only $37 \cdot 1 \%$ for the English one. This table also shows the mean (SEM) values for dependent variables according to whether they were excluded or included in the analysis. There were no significant differences between the mean values of those included and those excluded except for triceps skinfold which was less in those excluded in the inner city sample. The distribution of categorical variables between included and excluded children, however, was significantly different in most cases $(p<0.001)$.

Table 3 gives the final model of the variables associated with weight for height (SDS) in multiple regression analysis. Weight for height (SDS) was significantly associated with mother's education $(p<0 \cdot 05)$, one parent family ( $p<0.05)$, mother's BMI ( $<<0.001)$, father's BMI $(p<0.001)$, mother's hours of work $(p<0.05)$. The family size effect was modified in relation to ethnic origin $(p<0.005)$. However, the interaction was mainly due to the effect of a heterogeneous group which included Arab, Chinese, Vietnamese, Somalis, Sudanese, and 
Table 4 Associations between proxy indicators of obesity and biological and social environment factors. Models defined using multiple regression analysis

\begin{tabular}{|c|c|c|c|c|c|c|}
\hline \multirow[b]{2}{*}{ Variables } & \multicolumn{2}{|c|}{ Subscapular skinfold (SDS) } & \multicolumn{2}{|c|}{ Triceps skinfold (SDS) } & \multicolumn{2}{|c|}{ Subscapular $\mathcal{E}$ triceps skinfold (SDS) } \\
\hline & Coefficient (SEM) & $p$ value & Coefficient (SEM) & $p$ value & Coefficient (SEM) & p value \\
\hline Intercept & $-2 \cdot 226(0 \cdot 151)$ & & $-2 \cdot 454(0 \cdot 162)$ & & $-4.672(0.295)$ & \\
\hline $\begin{array}{l}\text { Drinks milk at school: } \\
\text { Yes }\end{array}$ & & 0.0014 & & & 0 & 0.0106 \\
\hline $\begin{array}{l}\text { Yes } \\
\text { No }\end{array}$ & $\begin{array}{l}0 \\
0.055(0.023)\end{array}$ & & & & $\begin{array}{l}0 \\
0.077(0.046)\end{array}$ & \\
\hline Unknown & $-0.140(0.056)$ & & & & $-0.252(0.109)$ & \\
\hline Birth weight & $0.117(0.018)$ & 0.0001 & $0.140(0.020)$ & 0.0001 & $0.256(0.036)$ & $0 \cdot 0001$ \\
\hline Mother's BMI & $0.040(0.002)$ & 0.0001 & $0.038(0.002)$ & 0.0001 & $0.078(0.005)$ & $0 \cdot 0001$ \\
\hline Father's BMI & $0.044(0.003)$ & 0.0001 & $0.043(0.003)$ & 0.0001 & $0.087(0.006)$ & 0.0001 \\
\hline Mother's age at child's birth & $0.006(0.002)$ & 0.0014 & $0.007(0.002)$ & $0 \cdot 0005$ & $0.013(0.002)$ & 0.0005 \\
\hline $\begin{array}{l}\text { Ethnic origin and family size interaction } \\
R^{2}\end{array}$ & $\begin{array}{l}* \\
(0 \cdot 08)\end{array}$ & 0.0080 & $\begin{array}{l}* \\
(0.08)\end{array}$ & $0 \cdot 0182$ & $\begin{array}{l}* \\
(0 \cdot 08)\end{array}$ & $0 \cdot 0048$ \\
\hline
\end{tabular}

* 80 levels not shown, but explained in the text.

other children who could not be classified into any of the large groups in the analysis. When this group was excluded from the analysis, the interaction was not significant. An interaction between age and birth weight was also found to be significant $(p<0.05)$. The increasing trend in weight for height with birth weight decreased with increasing age groups.

Table 4 gives the final model of the variables associated with subscapular, triceps and the sum of subscapular and triceps skinfold. In these three models, four variables were consistently associated in all models: birth weight, mother's BMI, father's BMI, and mother's age at the child's birth. The first order interaction

Table 5 Associations between child overweight and social and biological factors by multiple logistic regression analysis. $(n=8374)$

\begin{tabular}{|c|c|c|c|c|c|}
\hline Variables & No & $\begin{array}{l}\text { No (\%) } \\
\text { overweight }\end{array}$ & $O R^{*}$ & OR† & $95 \%$ CI \\
\hline $\begin{array}{l}\text { Family size: } \\
\quad 1 \\
2 \\
3 \\
4 \\
5 \\
\geqslant 6 \\
\text { Unknown }\end{array}$ & $\begin{array}{r}625 \\
3726 \\
2122 \\
798 \\
296 \\
212 \\
595\end{array}$ & $\begin{array}{r}196(31) \\
980(26) \\
524(24) \\
178(22) \\
51(17) \\
43(20) \\
133(22)\end{array}$ & $\begin{array}{l}1 \\
0 \cdot 78 \\
0.71 \\
0.62 \\
0.45 \\
0 \cdot 35 \\
0.63\end{array}$ & $\begin{array}{l}1 \\
0 \cdot 78 \\
0 \cdot 71 \\
0 \cdot 63 \\
0 \cdot 49 \\
0 \cdot 35 \\
0 \cdot 67\end{array}$ & $\begin{array}{l}(0.64,0.94) \\
(0.58,0.87) \\
(0.49,0.80) \\
(0.34,0.71) \\
(0.19,0.61) \\
(0.49,0.92)\end{array}$ \\
\hline $\begin{array}{l}\text { Mother's hours of work: } \\
>25 \mathrm{~h} / \mathrm{wk} \\
\text { Between } 15-25 \mathrm{~h} / \mathrm{wk} \\
<15 \mathrm{~h} / \mathrm{wk} \\
\text { No work outside home } \\
\text { Unknown }\end{array}$ & $\begin{array}{r}1599 \\
1776 \\
1182 \\
3443 \\
374\end{array}$ & $\begin{aligned} 472(29) \\
466(26) \\
293(24) \\
786(22) \\
88(23)\end{aligned}$ & $\begin{array}{l}1 \\
0 \cdot 84 \\
0.78 \\
0 \cdot 70 \\
0 \cdot 80\end{array}$ & $\begin{array}{l}1 \\
0 \cdot 91 \\
0 \cdot 82 \\
0 \cdot 80 \\
0 \cdot 50\end{array}$ & $\begin{array}{l}(0.77,1.07) \\
(0.69,0.99) \\
(0.69,0.92) \\
(0.58,1 \cdot 27)\end{array}$ \\
\hline $\begin{array}{l}\text { Mother's education: } \\
\text { Primary school } \\
\text { Secondary education } \\
\text { Further education } \\
\text { University/polytechnic } \\
\text { No school education } \\
\text { Unknown }\end{array}$ & $\begin{array}{r}272 \\
5216 \\
1690 \\
983 \\
155 \\
58\end{array}$ & $\begin{array}{r}56(20) \\
1320(25) \\
449(26) \\
251(25) \\
15(09) \\
14(24)\end{array}$ & $\begin{array}{l}1 \\
1 \cdot 31 \\
1.40 \\
1 \cdot 32 \\
0 \cdot 41 \\
1 \cdot 23\end{array}$ & $\begin{array}{l}1 \\
1 \cdot 20 \\
1 \cdot 28 \\
1 \cdot 29 \\
0 \cdot 50 \\
1 \cdot 28\end{array}$ & $\begin{array}{l}(0.87,1.64) \\
(0.91,1.78) \\
(0.90,1.83) \\
(0.27,0.94) \\
(0.64,2.55)\end{array}$ \\
\hline $\begin{array}{l}\text { One parent family: } \\
\text { Both parents at home } \\
\text { Only child's mother at home } \\
\text { Only child's father at home } \\
\text { Guardian or unknown }\end{array}$ & $\begin{array}{r}6917 \\
1069 \\
54 \\
334\end{array}$ & $\begin{array}{r}1719(24) \\
288(26) \\
22(40) \\
76(22)\end{array}$ & $\begin{array}{l}1 \\
1 \cdot 12 \\
2 \cdot 08 \\
0 \cdot 89\end{array}$ & $\begin{array}{l}1 \\
1 \cdot 35 \\
2 \cdot 26 \\
1 \cdot 25\end{array}$ & $\begin{array}{l}(1 \cdot 02,1 \cdot 78) \\
(1 \cdot 26,4 \cdot 04) \\
(0.75,2 \cdot 06)\end{array}$ \\
\hline $\begin{array}{l}\text { Father's social class: } \\
\text { I } \\
\text { II } \\
\text { IIIN } \\
\text { IIIM } \\
\text { IV } \\
\text { V } \\
\text { Unknown }\end{array}$ & $\begin{array}{r}333 \\
1910 \\
525 \\
2633 \\
929 \\
236 \\
1808\end{array}$ & $\begin{array}{r}68(20) \\
499(26) \\
112(21) \\
713(27) \\
216(23) \\
49(20) \\
448(24)\end{array}$ & $\begin{array}{l}1 \\
1 \cdot 38 \\
1 \cdot 06 \\
1 \cdot 45 \\
1 \cdot 18 \\
1 \cdot 02 \\
1 \cdot 28\end{array}$ & $\begin{array}{l}1 \\
1 \cdot 31 \\
1.01 \\
1 \cdot 37 \\
1 \cdot 18 \\
0.98 \\
1 \cdot 11\end{array}$ & $\begin{array}{l}(0.97,1 \cdot 76) \\
(0 \cdot 70,1 \cdot 44) \\
(1 \cdot 02,1 \cdot 85) \\
(0.85,1.64) \\
(0.64,1.52) \\
(0.76,1 \cdot 61)\end{array}$ \\
\hline $\begin{array}{l}\text { Child's birth weight: } \\
\text { 1st Quarter } \\
\text { 2nd Quarter } \\
\text { 3rd Quarter } \\
\text { 4th Quarter }\end{array}$ & $\begin{array}{l}2149 \\
2087 \\
2104 \\
2034\end{array}$ & $\begin{array}{l}406(18) \\
517(24) \\
564(26) \\
618(30)\end{array}$ & $\begin{array}{l}1 \\
1 \cdot 41 \\
1 \cdot 57 \\
1 \cdot 87\end{array}$ & $\begin{array}{l}1 \\
1 \cdot 36 \\
1.50 \\
1 \cdot 73\end{array}$ & $\begin{array}{l}(1.17,1.58) \\
(1.29,1.74) \\
(1.50,2.01)\end{array}$ \\
\hline $\begin{array}{l}\text { Parent's obesity: } \\
\text { Neither father nor mother obese } \\
\text { Father obese } \\
\text { Mother obese } \\
\text { Both obese }\end{array}$ & $\begin{array}{r}4929 \\
1393 \\
1361 \\
691\end{array}$ & $\begin{array}{l}955(19) \\
422(30) \\
421(30) \\
307(44)\end{array}$ & $\begin{array}{l}1 \\
1 \cdot 81 \\
1.86 \\
3.33\end{array}$ & $\begin{array}{l}1 \\
1 \cdot 85 \\
1.90 \\
3 \cdot 48\end{array}$ & $\begin{array}{l}(1 \cdot 61,2 \cdot 12) \\
(1 \cdot 66,2 \cdot 19) \\
(2 \cdot 93,4 \cdot 13)\end{array}$ \\
\hline
\end{tabular}

* Unadjusted odds ratio; $†$ adjusted odds ratio; $¥ 95 \%$ confidence interval for adjusted $O R$. between ethnic group and family size was also significant in these models. As in the analysis of weight for height, the interaction was mainly due to the ethnically heterogeneous group defined above and, in the analysis of subcutaneous skinfold, the Gujurati group also.

The pattern of association varied slightly within the four models shown in tables 3 and 4. Although birth weight and mother's and father's BMIs were associated in all models, the mother's age at the child's birth was only related to skinfold thickness, and mother's hours of work to the weight for height index only. A low percentage of variance was explained: in the weight for height model this was only $13 \%$ and in the models for triceps, subscapular, and the sum of triceps and subscapular skinfolds only $8 \%$. Birth weight and parental BMI were the variables that contributed most to the explained variance.

Table 5 shows the associations of over weight with independent variables using logistic regression analysis. In contrast to multiple regression analysis, social class was the only extra variable included in the final model $(p<0 \cdot 05)$. The interaction between family size and ethnic group was not significant and family size was included in the model, with a trend for the risk of overweight to decrease with increased family size $(p<0.001)$. The interaction between birth weight and age was not significant and birth weight was included in the model. The risk of overweight increased with birth weight. Those children at the top quarter of birth weight had a nearly twofold risk of overweight. A protective effect was found for children whose mothers worked for fewer than 15 hours a week outside the home or did not work at all. Those children with only one parent in the family were at a higher risk of overweight. When only the mother was present the OR was $1.35(95 \% \mathrm{CI}$ $1.02,1.78)$. When only the father was in the family, however, the risk increased to $2 \cdot 26$ (95\% CI $1 \cdot 26,4 \cdot 04)$. With regard to the social class of the father, only those in skilled manual occupation were at higher risk of overweight, the OR being $1.37(95 \%$ CI $1.02,1.85)$. The child's birth weight was also associated with overweight - as it increased, the risk of overweight increased. When both parents were obese, the OR increased to 3.48 (95\% CI 2.93 , $4 \cdot 13)$.

Multiple logistic regression analysis was also used to fit models for obesity defined by the 
upper quarter of subscapular, triceps, and the sum of triceps and subscapular skinfolds respectively. Birth weight and parent's obesity, as in the other models, were consistently associated in all three models. The interaction between family size and ethnic group was not significant, but family size and ethnic origin were independently associated in all three skinfold models $(p<0.001)$. Scottish, Punjabi, and Urdu children were at higher risk of obesity in the sum of subscapular and triceps skinfold model. In contrast to the multiple regression analysis of the continuous variables, mother's hours of work and mother's age at the child's birth were significantly associated with the outcome variable in all three logistic models.

\section{Discussion}

This analysis shows a consistent and highly significant association of all the measures of fatness with the parents's BMI and child's birth weight. In the multiple regression analysis there was also a consistent interaction between ethnic origin and family size for each of the dependent variables. In the logistic regression analysis the interaction was not significant and a highly significant association between overweight and fatness with number of children was shown. The strength of the remaining significant associations were slight and inconsistent in relation to the dependent variable or the type of analysis (multiple regression analysis or multiple logistic regression). Children in one parent families and those whose mothers worked outside the home were more overweight than other children, but these independent variables were not significant in relation to skinfold measurements. Older mothers had children with higher skinfold thickness values. Social class was significantly associated with weight for height in the logistic regression model, but with children of skilled manual fathers showing the highest percentage of overweight and those of unskilled manual workers one of the lowest.

The strengths of this analysis are the large number of children representing most sectors of English and Scottish society (including ethnic minorities), the large sample size studied, the large number of independent variables included in the analysis, and the high percentage of measurements taken from the eligible population. The main weakness of the analysis is the high percentage of missing values of reported parents' BMI. This meant that approximately half the children were excluded from the analyses. This was expected given the large percentage of children in families with only one parent at home and the large proportion of children from ethnic minorities with no reported measurement for a family member. As parents' BMI was the variable showing the strongest and most consistent association with measures of obesity we were reluctant to exclude this variable from the analysis or input values for missing information. There is a possibility that this type of analysis may miss some associations. However, the similarity of the current results with previous analyses on this topic, for the 1972 representative sample ${ }^{35}$ and for the 1983 inner city sample ${ }^{29}$ in which almost all children were included in all analyses or part of it, suggests that this possibility is less likely.

In the published action plan of the Nutrition Task Force ${ }^{43}$ it was stated that as a first step to combat obesity attention should be directed towards prevention rather than its treatment. In principle, this is a sound recommendation given the appreciable increase in obesity documented in children and adults in Britain and elsewhere. ${ }^{16-19}$ Our intention to re-examine the association between sociodemographic and biological factors and obesity, was to identify possible factors that may provide pointers to amenable areas for intervention. The association between the parents' BMI and the child's fatness is indicative of a familial influence. Twin studies suggest that a component of the association is of a genetic nature. ${ }^{445}$ Studies of parents and their adopted and biological children have shown that the association is stronger in biological than in adopted families. ${ }^{46}$ In support of the genetic mechanism of the association we would have expected the relation between father and child, and mother and child, to be of the same magnitude in all models. This was shown except in the weight for height model where the effect of the father's BMI was $40 \%$ higher than the mother's BMI. This might indicate that other environmental factors are important in explaining this relationship. As the mother is usually more in control of the home environment than the father we would have expected the effect to be greater for the mother's BMI. However, as related people share genes, environment, and lifestyle, it is probable that part of the familial association is due to environmental and lifestyle characteristics that are not easy to measure in population studies, such as physical activity, use of leisure time, and eating behaviour. A further argument in favour of environmental factors is the marked increase of obesity in the population in a period of 20 years. ${ }^{197}$ This phenomenon cannot be accounted for by changes in gene frequency in this short time.

Given the strong familial association of obesity it is important to examine the place of prevention in the family. Intervention strategies considering the family as a unit, rather than the child, need to be evaluated in terms of their efficacy and costs. One possible strategy would be that families who are more prone to obesity need to be targeted for intervention studies. Stunkard $e t a \beta^{34}$ suggested that attempts should be targeted at those at high risk of obesity. This is not the strategy that we would support. Firstly, because the explained variation in child fatness in our study has been consistently low and most children at high risk of obesity will be left out. Secondly, overweight and obesity are a widespread problem in Britain; around $50 \%$ of men and $40 \%$ of women have a BMI over $25{ }^{47}$ Thirdly, it would be very difficult to identify obese parents and such identification may stigmatise some of the children in the programme and their families. However, primary care workers and school staff should be aware that obese parents are more likely to 
have obese children. Thus, to focus advice only on the child may create problems within the family as the child may have limited scope for changing his lifestyle and environment.

The significant interaction of ethnic background and number of children on obesity, mainly due to one ethnic group in the analysis, is indicative of the complexity of the issues that need to be taken into account. In the white sample there is a strong negative association between number of children and obesity. In the logistic regression, in which the interaction was not significant, there was a strong negative association between the number of children and overweight and fatness. However, this association has not been demonstrated consistently in non-white groups in Britain. ${ }^{29}$ This indicates that the number of children in the family is not directly related to obesity in the white population, but is a proxy for other factors that may be related to values or social characteristics associated with family size.

Of the remaining significant associations in our analysis, birth weight is one that is consistently associated with fatness. These results are consistent with other studies. ${ }^{3348}$ However, it is difficult to imagine a preventive action that can be derived from this association as most health actions are geared to decrease the percentage of light for date newborns in Britain. The significant interaction of birth weight and age on weight for height may indicate that birth weight is a less important factor in the overweight of older children. However, as the interaction was not significant in the assessment of skinfold thickness we are uncertain of this interpretation. The association of birth weight with fatness is puzzling in relation to the Barker hypothesis. ${ }^{49}$ Obesity is a known contributor to raised blood pressure and total cholesterol levels. Our result indicates that birth weight has a complex effect on risk factors associated with coronary heart disease.

The findings that children whose mother's work outside the home and those in one parent families tended to be more overweight is potentially important. The common characteristic of these two factors is that these children may spend long periods of time on their own and they may eat more frequently than other children. It is difficult to explain from our analysis, however, why this phenomenon is associated mainly with weight for height and not skinfold thickness (except mother's hours of work in the logistic regression). Because we included triceps and subscapular skinfold thickness, it is not possible to hypothesise that distribution of fat may be an explanation. At this stage we would only recommend health workers in the community to be aware of this finding, rather than to act on it.

Mother's age at delivery was related to skinfold thickness but not weight for height. We have consistently shown that the mother's age at delivery is associated with the child's height, ${ }^{50}$ but it is the first time that we have reported a relation with fatness. Our result suggests that the reason why the children of older mothers are taller may be related to the fact that these children are fatter and may be more ad- vanced in their prepubertal maturation as it is well known that fat children, especially girls, tend to be more advanced in their physiological maturation. ${ }^{51}$ It is curious that this association, which was highly significant with skinfold thickness, was not significant with weight for height. We cannot provide an explanation for this finding that is unlikely to be due to chance.

In conclusion, very few variables are associated with measures of overweight and fatness. The only useful factor which is highly associated with all measures of fatness is the parent's BMI. This association may indicate that there are families who are susceptible to becoming obese. We believe that programmes to prevent obesity should take this factor into account. As the percentage of explained variation in our study is low, it would be unwise to focus prevention only on children whose parents are obese. Primary prevention strategies of childhood obesity should be aimed at the total population and special emphasis should be put on those families in which one or both parents is overweight. Any primary prevention programme, however, should be carefully evaluated and monitored. Only interventions of proved effectiveness should be supported. The rest of the variables associated with overweight or obesity do not provide potential for action or the inconsistency of the associations may only provide helpful pointers. Of these the most interesting finding is that children who spend a long time on their own may be more prone to become obese. To progress further, it is possible that measures which look at other events in the child's life such as physical activity, eating behaviour, and use of leisure time need to be developed for use in large surveys.

The writers thank all children, parents, teachers, doctors, administrators, nurses and clerks in the areas and schools, for their participation in the study and Professor W W Holland, their participation in the study and Professor $\mathrm{W}$. Holland, the fieldworkers, and the administrators in the department for is supported by the Department of Health and the Scottish is supported by the Department
Home and Health Department.

1 Garrow JS. Obesity and overweight: a briefing paper prepared for the Health Education Authority. London; Health Education Authority, 1991:29.

2 Anonymous. National Institutes of Health consensus development conference statement. Health implications of obesity. Ann Intern Med 1985;103:147-52.

3 Kissebah AH, Freedman DS, Peiris AN. Health risks of obesity. Med Clin North Am 1989;73:111-38.

4 Bray GA. Overweight is risking fate. Definition, classification, prevalence and risks. Ann NY Acad Sci 1987; 499:14-28.

5 Lew, EA, Garfinkel L. Variations in mortality by weight among 750000 men and women. $\mathcal{F}$ Chronic Dis 1979;32: 563-76.

6 Waaler HT. Height, weight and mortality: the Norwegian experience. Acta Med Scand 1984;679(Suppl): 1-56.

7 Rabkin SW, Mathewson FA, Hsu PH. Relation of body weight to development of ischaemic heart disease in weight to development of ischaemic heart disease in cohort of young North American men after a 26 year observation period:

8 Manson JE, Colditz GA, Stampfer MJ, Willet WC, Rosner B, Monson A. A prospective study of obesity and risk of coronary heart disease in women. $N$ Engl F Med 1990 322:882-9.

9 Simopoulos AP, Van Itallie TB. Body, weight, health and longevity. Ann Intern Med 1984;100:285-95.

10 Mossberg, HO. 40 year follow-up of overweight children Lancet 1989;ii:491-3.

11 Nieto FJ, Szklo M, Comstock GW. Childhood weight and growth rate as predictors of adult mortality. Am $\mathcal{F}$ Epidemiol 1993;136:201-13.

12 Somerville SM, Rona RJ, Chinn S. Obesity and respiratory symptoms in primary school. Arch Dis Child 1984;59. 940-4.

13 Gortmaker SL, Must A, Perrin JM, Sobol AM, Dietz WH. 
Social and economic consequences of overweight in adolescence and young adulthood. N Engl F Med 1993;14: 1036-7.

14 Gulliford MC, Rona RJ, Chinn S. Trends in body mass index of young adults in England and Scotland from 1973 to 1988. F Epidemiol Community Health 1992;46:187-90

15 Gregory J, Foster K, Tyler H, Wiseman M. The dietary and nutritional survey of British adults. London: Social Survey Division, Office of Population Censuses and Surveys, HMSO. 1990:392.

16 Kuskowska-Wolk A, Bergstrom R. Trends in body mass index and prevalence of obesity in Swedish men 1980-89. index and prevalence of obesity in Swedish men

17 Gortmaker SL, Dietz WH, Sobol AM, Wehler ChA. Increasing pediatric obesity in the United States. Am $\mathcal{F}$ Dis Child 1987;141:535-40.

18 Kuczmarski R, Flegal K, Campbell S, Johnson C. Increasing prevalence of overweight among US adults. The National Health and Nutrition Examination Surveys, 1960 to 1991. fAMA 1994;272:205-11.

19 Chinn S, Rona RJ. Trends in weight-for-height and triceps skinfold thickness for English and Scottish children, 19721982 and 1982-1990. Paediatr Perinat Epidemiol 1994;8: 90-106.

20 Braddon FE, Rodgers B, Wadsworth ME, Davies JM. Onset of obesity in a 36 year birth cohort study. $B M \mathcal{F} 1986 ; 293$ : 299-302.

21 Stark O, Atkins E, Wolff OH, Douglas JW. Longitudinal study of obesity in the national survey of health and study of obesity in the national sur
development. BMF 1981;283:13-7.

22 Taitz LS. The obese child. Oxford: Blackwell Scientific Publications. 1983:142-8.

23 Lloyd J, Wolff OH, Whelen WS. Childhood obesity. A long term study of height and weight. $B M \mathcal{F} 1961 ; \mathrm{i}: 145-8$.

24 Court JM. Obesity in childhood. Med F A A st 1977;1:888-91.

25 Rolland-Cachera MF, Deheeger M, Guilloud-Bataille M, Avons P, Patoris E, Sempé M. Tracking the development of adiposity from one month of age to adulthood. $A n n$ Hum Biol 1987;14:219-29.

26 Dietz WH, Gortmaker SL. Factors within the physical environment associated with childhood obesity. Am $\mathcal{}$ Clin Nutr 1984;39:619-24.

27 Lissau-Lund-Sorensen I, Sorensen TI. Prospective study of the influence of social factors in childhood on risk of overweight in young adulthood. Int $\mathcal{f}$ Obes 1992;16:16975 .

28 Locard E, Mamelle N, Billette A, Miginiac M, Munoz F, Rey S. Risk factors of obesity in a five year old population. Parental versus environmental factors. Int $\mathcal{F}$ Obes 1992; 16:721-9.

29 Rona RJ, Chinn S. National Study of Health and Growth: social and biological factors associated with weight-forheight and triceps skinfold of children from ethnic groups in England. Ann Hum Biol 1987;14:231-48.

30 Darwish OA, Khalil MH, Sarhan AA, Ali HE. Aetiological factors in obesity in children. Human Nutrition-Clinical Nutrition 1985;39:131-6.

31 Shukla A, Forsyth HA, Anderson CM, Marwah SM. Infantile overnutrition in the first year of life: a field study in Dudley, Worcestershire. BMf 1972;4:507-15.

32 Keiller SM, Colley JR, Carpenter RG. Obesity in school children and their parents. Ann Hum Biol 1979;6:443-55.

33 Rona RJ, Chinn S. National Study of Health and Growth: social and family factors and obesity in primary school children. Ann Hum Biol 1982;9:131-45.

34 Stunkard A, D'Aquili E, Fox S, Filion RD. Influence of social class on obesity and thinness in children. $7 A M A$ 1972;221:579-84.

35 Chinn S, Rona RJ. Secular trends in weight, weight-forheight and triceps skinfold thickness in primary school children in England and Scotland 1972 to 1980 . Ann Hum Biol 1987;14:311-9.

36 Rona RJ, Altman DG. National Study of Health and Growth: standards of attained height, weight and triceps
skinfold in English children 5 to 11 years old. Ann Hum skinfold in English chil

37 Osborn AF, Butler NR, Morris AC. The social life of Britains' five year olds. A report of the child health and education study. London; Routledge and Kegan Paul, 1984.

38 Tanner JM, Whitehouse RH, Takaishi M. Standards from birth to maturity for height, velocity, and weight velocity: British children, 1965. Arch Dis Child 1966;41:454-71, 613-35.

39 Tanner JM, Whitehouse RH. Revised standards for triceps and subscapular skinfolds in British children. Arch Dis Child 1975;50:142-45.

40 Chinn S. A new method for calculation of height centiles for preadolescent children. Ann Human Biol 1992;19: for preadi

41 Chinn S, Rona RJ, Gulliford MC, Hammond J. Weight for height in children aged 4 to 12 years. A new index compared to the normalized body mass index. Eur $\mathcal{F}$ Clin Nutr 1992;46:489-500.

42 Cole TJ. Fitting smoothed centile curves to reference data (with discussion). Fournal of the Royal Statistical Society $A$ 1988;151:385-418.

43 Clayton B. Department of Health. Eat well! An action plan from the nutrition task force to achieve the health of the nation targets on diet and nutrition. In: The health of the nation. London: Department of Health 1994:44.

44 Brook CG, Huntley RM, Slack J. Influence of heredity and environment in determination of skinfold thickness in children. $B M \mathcal{F}$ 1975;ii:719-21.

45 Bodurtha JN, Mosteller M, Hewitt JK, et al. Genetic analysis of anthropometric measures in 11 year old twins: The Medical College of Virginia twin study. Pediatr Res 1990; 28: $1-4$

46 Stunkard AJ, Sorensen TI, Harnis C, Teasdale TW, Chakrabosty R, Schull WJ, Schulsinger F. An adoption study of human obesity. N Engl $\mathcal{F}$ Med 1986;314:193-98.

47 White A, Nicolaas G, Foster K, Browse F, Cavey S. Health survey for England 1991. Social Survey Division, Office of Population censuses and surveys. London: HMSO 1993: 359

48 Maffeis C, Micciolo R, Must A, Zaffanello M, Pinelli L. Parental and perinatal factors associated with childhood obesity in north-east Italy. International fournal of Related Metabolic Disorders 1994;18(5):301-5.

49 Barker DJB, ed. Fetal and infant origin of adult disease. (n) ongin

50 Gulliford MC, Chinn S, Rona RJ. Social environment and height: England and Scotland 1987 and 1988. Arch Dis Child 1991:66:235-40.

51 Garn SM, Haskell JA. Fat thickness and developmental status in childhood and adolescence. Am $\mathcal{F}$ Dis Child 1960; 99:746-51. 